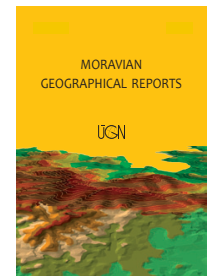

MORAVIAN GEOGRAPHICAL REPORTS

\title{
Distance matters. Assessing socioeconomic impacts of the Dukovany nuclear power plant in the Czech Republic: Local perceptions and statistical evidence
}

\author{
Bohumil FRANTÁL ${ }^{\text {a }}$, Jiří MALÝ a ${ }^{\text {a }}$ Martin OUŘEDNÍČEK ${ }^{\mathrm{b}}$, Jiří NEMEŠKAL ${ }^{\mathrm{b}}$
}

\begin{abstract}
The effect of geographical distance on the extent of socioeconomic impacts of the Dukovany nuclear power plant in the Czech Republic is assessed by combining two different research approaches. First, we survey how people living in municipalities in the vicinity of the power plant perceive impacts on their personal quality of life. Second, we explore the effects of the power plant on regional development by analysing long-term statistical data about the unemployment rate, the share of workers in the energy sector and overall job opportunities in the respective municipalities. The results indicate that the power plant has had significant positive impacts on surrounding communities both as perceived by residents and as evidenced by the statistical data. The level of impacts is, however, significantly influenced by the spatial and social distances of communities and individuals from the power plant. The perception of positive impacts correlates with geographical proximity to the power plant, while the hypothetical distance where positive effects on the quality of life are no longer perceived was estimated at about $15 \mathrm{~km}$. Positive effects are also more likely to be reported by highly educated, young and middle-aged and economically active persons, whose work is connected to the power plant.
\end{abstract}

Keywords: nuclear power plant impacts; spatial analysis; risk perceptions; geographical distance; social distance; Dukovany; Czech Republic

Article history: Received 21 September 2015; Accepted 15 February 2016; Published 31 March 2016

\section{Introduction}

Growing concerns over global climate change, energy sustainability and energy security over the last decade have led to rapid and widespread development of renewable energies. The generous feed-in tariffs for renewable energy in Germany have been so effective that Chancellor Merkel was able to announce the closure of Germany's nuclear program after the Fukushima nuclear accident (Jahn and Korolczuk, 2012). Nonetheless, renewable energy development has been uneven around the world and it still represents but a small part of total generation in most countries (Eurostat, 2015). For this reason, governments need to reconsider conventional sources, such as fossil fuels and nuclear power.

Although it has always been associated with significant social controversy, nuclear power capacity worldwide has been increasing steadily. Today there are more than 435 nuclear reactors operating in 31 countries, with a total installed capacity of over $375 \mathrm{GW}$. In 2014, these provided 2,411 TWh, which is over $11 \%$ of the world's electricity (WNA, 2015). Some 60 new reactors are currently being constructed in 13 countries, while significant further capacity is being created by existing plant upgrading and rebuilding programs (ibid.).

The Czech Republic - with its two nuclear power plants (Dukovany and Temelín) generating over $30 \mathrm{TWh}$ - is among the top fifteen world nuclear producers. The Czech population is also among the largest supporters of nuclear power usage in Europe, with about two-thirds being in favour of nuclear power development (CVVM, 2015). Nuclear power is expected by the current Czech government to become the main source of electricity production, with its share increasing from the present $35 \%$ to between $46 \%$ and $58 \%$ in 2040 (WNA, 2015). Recently a new long-term plan for the

\footnotetext{
${ }^{a}$ Department of Environmental Geography, Institute of Geonics, The Czech Academy of Sciences, Brno, Czech Republic (*corresponding author, B. Frantál, email: frantal@geonika.cz)

${ }^{\mathrm{b}}$ Department of Social Geography and Regional Development, Faculty of Science, Charles University in Prague, Prague, Czech Republic
} 
nuclear industry - involving building at least three new units by 2040 - was approved, in order to be able to decarbonise the economy and to replace the dominant role of lignite in the energy mix.

Nevertheless, increasing construction costs, high state subsidies, and uncertainties concerning future decommissioning, nuclear waste disposal and possible accidents, remain the most common arguments of opponents of nuclear power (Cooper, 2010). On the other hand, the large power-generating capacity, low pollution and relatively low operating costs are stressed by its supporters. Saying that nuclear power supports the socioeconomic development of host regions has also become a popular policy turn of phrase to stimulate social acceptance. The plans for a life-time extension of old reactors and the building of a new one at the Dukovany power plant site in the Czech Republic have been strongly supported by regional authorities and the Energoregion 2020 association, which includes representatives of 126 local municipalities (Energoregion, 2020). The Dukovany power plant is promoted not only as a key contributor to national energy security but also as an important source of jobs, a basis for increasing the educational level of the population, economic stabilisation and the overall standard of living in the region.

Thus, it is a question whether political proclamations about the positive impacts of the nuclear power plant (hereinafter NPP) are in accordance with the subjective perceptions of residents of the local communities and with more objective data sources. Some studies from other countries (e.g. Yamane et al., 2011) reported that impacts of NPPs on the economic welfare and well-being of local communities have not always been positive. Such may also be the case for the second Czech NPP in Temelín, where the local community's expectations of the benefits are said to be far from fulfilled (Baroch, 2010). Pidgeon et al. (2009) pointed out that 'geography matters' in this context. In other words, NPPs can contribute economically to nearby communities, but not to others farther away who might perceive themselves to be at risk.

To address this complex issue and the role of geographic space in this respect (i.e. to assess how much the positive and/or negative impacts of nuclear power plants are spatially differentiated), we elaborate two different approaches to research on the impacts of the Dukovany NPP. First, we explore how people living in municipalities in the hinterland of the power plant subjectively perceive the impacts on their personal quality of life and the development of their communities. Second, we assess the impacts of the nuclear power plant on regional development by analysing longterm statistical data about some selected socio-economic characteristics of the municipalities. The results of these two approaches are compared in the final discussion section of the paper.

\section{Theoretical background}

The theoretical background is provided by a review of the relevant literature, structured around the three main aspects of nuclear energy development which have been reflected in social science and particularly human geographical research. The first aspect is general public attitudes towards nuclear energy and the social acceptance of planned NPPs; the second is the socioeconomic effects of existing power plants on host regions; and the third is the perception of positive and negative impacts of power plants by residents of local communities. While the literature dealing with the first aspect is vast and comprehensive, that relating to the more objective socioeconomic impacts of operational power plants, as well as perceptions of such impacts, is much more limited, including a few case studies, the majority of them from the United States and the United Kingdom.

\subsection{Risk perceptions and public attitudes to nuclear power plants}

The rapid rise of nuclear technologies in the 1960s revealed a marked discrepancy between the enthusiasm for a new, powerful, clean and safe energy source documented by scientific experts, and the fears of immediate disasters and unknown long-term health and environmental effects on the part of the general public. This discrepancy lay behind the boom in social science research on risk perceptions (Starr, 1969; Slovic et al., 1979; Fischhoff et al., 1983). Psychometric research (Fischhoff et al., 1978; Slovic, 1987) revealed that ordinary people perceive, evaluate and accept hazardous technologies and activities less on the statistical probability of the realisation of risks, than on the basis of qualitative attributes of these risks, such as novelty or familiarity, controllability, predictability, immediacy, etc.

The qualitative aspects of risks play a crucial role in public perceptions of nuclear energy, and reactions such as fear and anxiety seem to be the major determinants of attitudes to the building of NPPs (Van der Pligt, 1985; Van der Pligt et al., 1986). It has been shown that there are differences in the perception of risks according to gender, age, education and ethnicity, as well as according to cultural contexts (Dake, 1992; Flynn et al., 1994). Later studies criticising simple psychometric or cultural theory models of risk perception emphasised that risk perception is a much more complex, multidimensional and socially amplified phenomenon (Goodfellow et al., 2011).

Differences in the perception of risks, however, do not embrace all of the relevant aspects of public acceptance of nuclear energy. Public attitudes can be motivated by different goals, including the overall evaluation of costs and benefits, moral dispositions, and subjective feelings related to the nuclear technology (Visschers et al., 2011); they are dependent on socioeconomic status, education and knowledge of energy matters (Bazile, 2012; Pampel, 2011). For example, a survey of more than 3,000 US residents (Greenberg and Truelove, 2001) found that the pro-nuclear group was disproportionately composed of affluent, educated white males, while the pro-coal group included more relatively poor, less educated African-American and Latino females. Apart from the perception of the technology, acceptance is significantly affected by the way that the technology is implemented (Venables et al., 2012), and how the costs and benefits of power plants are distributed: i.e. the factors of procedural fairness, distributional fairness and trust in the available information and the intentions of policymakers and companies (Visschers et al., 2011; Visschers and Siegrist, 2012).

\subsection{Socioeconomic impacts of nuclear power plants on host localities}

The NPPs have a range of socioeconomic implications for their host localities: some direct through local employment in the development; others more indirect, resulting from the filtering of income and expenditures through and into the local community (see, e.g. McGuire, 1983; Bezdek and Wendling, 2006). It is necessary to distinguish between the effects associated with the construction stage and 
those with the operational stage. Most authors highlighted the significance of those longitudinal effects of plants on their host regions, while the local economic impact of the construction phase has been considered minor due to a dispersed commuting pattern by construction workers (Peelle, 1976). Moreover, the construction stage is prone to various negative effects for local communities, such as traffic growth, disturbance of the local accommodation markets caused by an influx of in-migrants, and increase in levels of crime and other behavioural problems (Glasson, 2005).

The effects on employment and tax revenues have been mentioned among the most relevant long-term benefits of nuclear power plants (Isard et al., 1976; Johnson and Bennett, 1979; McGuire, 1983). The second-order consequences of the direct economic impact may include changes in community land use policies, an increase in the salience of growth issues, and alteration of both interand intra-community relationships (Peelle, 1976). On the other hand, negative effects of the power plants on the attractiveness of the locality and residential property values, a potential outflow of population and a decline of local tourism and second-home development, are the most frequently discussed.

Many prejudices, myths and unfounded fears have spread around the siting of either nuclear power plants or nuclear waste storage sites. In this context, Metz (1994) stressed that there are several paradoxes or contradictions between the responses expressed in surveys and recorded economic and demographic behaviours evidenced in the marketplace. Policymakers then need to evaluate whether the request for a change in siting policy is based on subjective fear of a potential negative economic effect, or on proven negative effects.

While studies of the negative externalities of coal-fired power plants (e.g. Davis, 2011) found that neighbourhoods of power plants experienced significant decreases in property values and rents, no similar correlation has so far been detected for nuclear power plants either in the US or Europe (Gamble and Downing, 1982; Clark et al., 1997; Horská et al., 1996). A recent study from Japan (Yamane et al., 2011) reported that the neighbourhoods are negatively evaluated by their residents (reporting that their economic welfare is worsened by living near the plants) in the case of some NPPs, whereas there are no evaluations or even positive ones at other different locations. Meta-analysis detected that these differences are affected by contextual and social factors, such as how long the plant has been in operation, past accidents, population density, changes in employment and industrial structure, financial conditions and changes in social infrastructures in the areas. In summary, this study showed that the construction and operation of hazardous energy facilities do not necessarily lower the local residents' welfare, and that a potential decline can be mitigated if the host community receives enough of the benefits that it had expected in return for accepting the plants.

\subsection{Public perceptions of impacts: the effect of distance(s)}

Perceptions of and attitudes to nuclear power plants have been shown to be not static, but dynamic and spatially-shaped phenomena. Common themes of research on energy facility sitting have been to investigate the effects of the so-called 'NIMBY syndrome' and the 'proximity hypothesis', which assumed that those living nearer to energy facilities are likely to have more negative attitudes in comparison to those living further away (see, e.g. Boholm and Löfsted, 2004; Van der Horst, 2007). Dear (1992: 291) suggested that "the closer residents are to an unwanted facility, the more likely they are to oppose it". Many studies (e.g. Maderthaner et al., 1978; Eiser et al., 1995; Greenberg, 2009a, 2009b; Frantál, 2005) reported the opposite - that people living close to existing power plants perceive them more positively and are likely to accept them more, than people living farther away. The proximity hypothesis, however, has not been definitively falsified, and it is even supported by some recent research on the local acceptance of renewable energy projects (Jones and Eiser, 2010; Swofford and Slattery, 2010).

Warren et al. (2005) reported a strong positive effect of distance on the dislike for proposed wind power plants, and a much weaker negative effect of distance on the dislike of existing wind power plants. It is evident that the timespace dynamics of local opposition are complex phenomena and that the role of geographical proximity differs largely with respect to the type of technology and the stage of development, as well as to specific local contexts. In addition, 'distance' itself must be qualified. In this sense, DevineWright (2005) in the context of perception and acceptance of wind power plants, indicates that 'social distance' (the effect of social influence and social networks on the formation of opinions) can be a more important factor than geographical proximity. In social science generally, social distance has been used to measure the degree of closeness or remoteness people feel toward other groups. Extensively used today in studies of ethnic, class, gender, status and many other kinds of social relations, social distance is most often measured following the Bogardus 'Social Distance Scale', or some modification of it (Ethington, 1997). In the context of this study, we use the term 'social distance' to indicate the (socioeconomic) relationship of people to the NPP: i.e. a measure based on the degree of familiarity and interactions with the NPP, and their ability to participate in the economic benefits generated by the power plant. We expect that people working in plant itself will be, in this sense, socially closest to it - no matter how physically close or far from it they live.

The attitudes of residents of local communities to NPPs usually develop from very critical during the planning and construction phase to more tolerant or even positive after a certain time of operation. The acceptance of existing NPPs, which is constructed through the processes of familiarisation and normalisation of risks as a part of everyday life, co-exists here with a more complex set of contradictions (risk, threat and anxiety as a part of everyday life) (Parkhill et al., 2010). The experience of having lived near a NPP affects not only public perceptions of the various potential costs and (especially economic) benefits, but also the importance people attach to the various consequences (Van der Pligt et al., 1986).

In contrast to the familiarisation of risks and adaptation to a new local identity, attitudes towards a specific project or technology can deteriorate due to some external factors (e.g. the effect of nuclear accidents such as those in Chernobyl and Fukushima - see, e.g. Eiser et al., 1989; Lindell and Perry, 1990; Siegrist and Visschers, 2013; Siegrist et al., 2014), or because the expectations of local communities concerning the scale of costs and benefits have not been met. It has been suggested that, in the case of rebuilding and re-powering older NPPs, the local residents' own personal experiences, perceived benefits and outcome fairness are some key determinants of acceptance of the decision, while procedural fairness and trust have only a limited impact (e.g. Visschers and Siegrist, 2012). 
In this sense, greater attention should be paid to research on the ex-post perceptions of the outcomes of existing power plants and the 'asymmetries of impact' (Walker et al., 2014). The primary objective of this study is to assess the effect of geographical distance on the intensity of socioeconomic impacts of nuclear power plants on surrounding communities. In this sense, we intend to support or falsify the proximity and NIMBY theories in the context of nuclear energy development. The methodological contribution of this paper to current knowledge is represented by our two approaches: (i) we apply an integrative research approach which confronts subjective and objective dimensions of the issue (assessing socioeconomic impacts as perceived by residents of local communities, as well as that evidenced by official statistical data); and (ii) in addition to assessing the influence of geographic distance on public perceptions, we identify and evaluate the socio-demographic factors that determine the 'social distance' of people from the nuclear power plant.

\section{Research methodology}

\subsection{Area under study}

The Dukovany NPP is located near the municipality of Dukovany, situated on the border of the Vysočina and the South Moravian regions. The power plant consists of four pressurised-water reactors, each of which has a heat capacity of 1,375 MW and an electric capacity of $510 \mathrm{MW}$. The first reactor unit was put into operation in 1985 and the last one in 1987. The average annual production of electrical energy approaches a value of more than $13 \mathrm{TWh}$, which represents about $20 \%$ of the total consumption of electricity in the Czech Republic. The NPP is owned and operated by the ČEZ Group: the largest utility as well as the largest public company in Central and Eastern Europe.

For the purposes of this research, we divided neighbouring municipalities into three categories, set up on the basis of zones within a radius of 5,10 and $20 \mathrm{~km}$ from the power plant (see Fig. 1). These zones delimit the area that is affected by the activities of the NPP (including plans for a possible nuclear accident), and also includes municipalities with direct financial support from the ČEZ company. The zones are officially established in the 'External Emergency Plan' (EEP), which is the basic document addressing measures to protect the population, the environment and properties in the event of a nuclear accident. The 'Zone of Emergency Planning' (ZEP) includes some 138 municipalities with a total population of nearly 100,000 (see Tab. 1).

This delimitation of zones has also been used by the ČEZ company for the purpose of allocation of financial support to surrounding communities. Financial support (in the form of financial donations, support for development projects or various sponsorship activities) has been directed primarily to

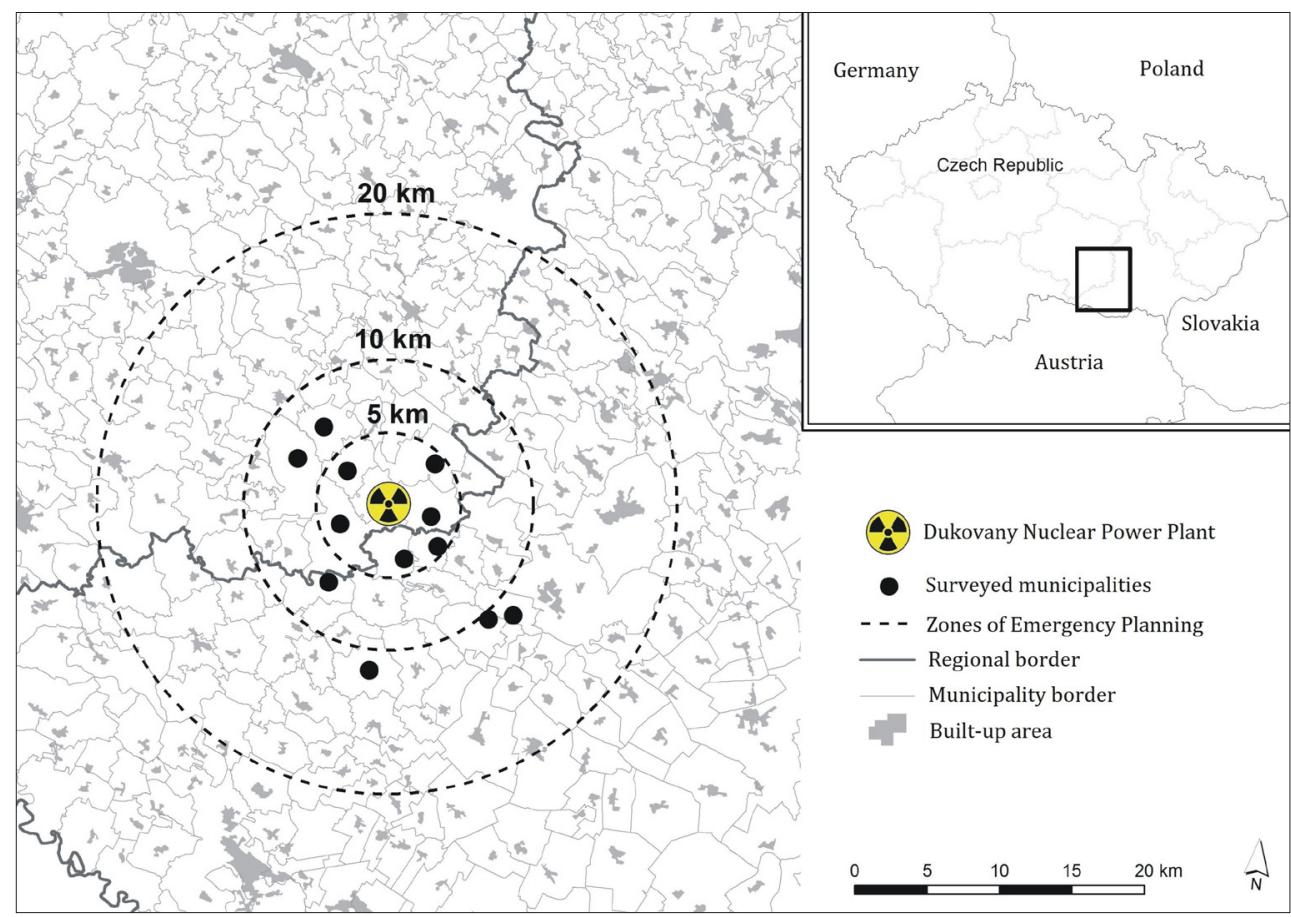

Fig. 1: Area under study

\begin{tabular}{lccccc}
\hline Zone & $\begin{array}{c}\text { Number of } \\
\text { municipalities }\end{array}$ & Population & $\begin{array}{c}\text { Economically } \\
\text { active population } \\
\text { (EAP) }\end{array}$ & \multicolumn{2}{c}{$\begin{array}{c}\text { Commuters to work to Dukovany } \\
\text { municipality }\end{array}$} \\
\hline Zone I & 6 & 4,199 & 1,644 & 117 & Number \\
Zone II & 29 & 8,972 & 3,395 & 149 & 4.1 \\
Zone III & 103 & 83,145 & 32,333 & 314 & 1.0 \\
Total & $\mathbf{1 3 8}$ & $\mathbf{9 6 , 3 1 6}$ & $\mathbf{3 7 , 3 7 2}$ & $\mathbf{5 8 0}$ & $\mathbf{1 . 6}$ \\
\hline
\end{tabular}

Tab. 1: Basic characteristics of the area under study

Source: Population Census 2011 (CZSO, 2011); authors' calculations 
municipalities within the ZEP, although there are exceptions such as support for the cities of Třebíč and Brno, which are important for the life of the inhabitants of the ZEP (providing health and social services, education, etc.).

Municipalities located in the inner emergency zone have obtained, relatively, the highest levels of financial support through donations from specific contracts. The so-called "Agreement on good neighbourhood" between the ČEZ and the six closest municipalities includes clauses on mutual information about activities and plans of the company and communities, mutual assistance in solving some problems, the pursuit of long-term regional development, and improvement of living conditions and civic amenities (according to Šilhán, 2011, p. 19). Based on this agreement, ČEZ provided municipalities with annual financial donations. The municipalities reciprocated in providing ČEZ advertising, sought to educate residents about the power plant's safety and environmental impacts, and they undertook to provide no support for protest actions against the company (ibid.).

Moreover, Dukovany and Rouchovany municipalities benefit from the fact that the NPP is located in their cadastral areas. As such, their incomes are significantly increased by property taxes, which account for more than 10 million CZK (appr. 370,000 EUR) annually. Rouchovany also benefits from the fact that the short-term storage of spent nuclear fuel is located in its cadastral area (the annual contribution is about 3 million CZK (appr. 110,000 EUR)). It can then be hypothesised that the most visible positive economic impact of the NPP on local development, as well as the most positive perception of the power plant, should be in such communities located within the inner emergency zone, and particularly in the municipalities of Dukovany and Rouchovany.

\subsection{Methods and data}

During December 2013 and January 2014, we carried out a standardised questionnaire survey of residents in local communities living in the vicinity of the power plant, to explore how they perceive the impacts of the power plant on their personal quality of life and the development of their communities. Given these data, we were able to evaluate the extent to which these perceptions were spatially and socially differentiated. The questionnaires were completed via on-site interviews (in peoples' homes or on the street) by trained interviewers. Potential respondents were selected by quota sampling procedures, with respect to their basic demographic characteristics in order to represent the population of the region. The sample involved a total of 582 respondents, including 294 people living in the six municipalities in Zone I, 196 people living in the three selected municipalities in Zone II, and 92 people living in the three selected municipalities in Zone III. The basic characteristics of respondents are summarised in Tab. 2: the sample approximates the target population quite well.

Some distortion of the results, particularly as concerns the spatial differentiation of perception of impacts in municipalities in the third zone and the estimation of "zero effect distance" (a hypothetical distance where positive effects on the personal quality of life are no longer perceived), may be present as a consequence of the small sample of municipalities, as well as the location of all surveyed municipalities at a maximal distance of $14 \mathrm{~km}$ from the power plant. Nevertheless, this study was not aimed primarily at the estimation of absolute numbers but rather at exploring specific relative numbers and relationships, particularly differences between the municipalities in the first zone (with the highest direct economic profits) and other zones, and differences with respect to the socio-demographic characteristics of residents.

Following the survey of perceived impacts, we assessed the regional impacts of the NPP by analysing long-term official statistical data indicative of selected socioeconomic characteristics of the municipalities in the vicinity of power plant and in the wider region. In this paper, we focus specifically on the two key indicators that are most often mentioned in connection with the positive effects of nuclear power plants - job opportunities and the unemployment rate. These indicators represent important measures of economic advancement in the region and municipalities. For

\begin{tabular}{llc}
\hline \multirow{2}{*}{ Indicator } & Category & Share [\%] \\
\cline { 3 - 3 } Gender & Male & in Sample (in Target Population) \\
Age (years) & Female & $51(50)$ \\
& less than 20 & $10(20)$ \\
& $20-29$ & $14(13)$ \\
& $30-39$ & $18(15)$ \\
& $40-49$ & $15(14)$ \\
Education & $50-59$ & $18(13)$ \\
& $60-69$ & $15(13)$ \\
& 70 and more & $10(12)$ \\
& Basic & $16(19)$ \\
& Secondary without GCE & $36(37)$ \\
Work in plant & Secondary with GCE & $36(31)$ \\
& Tertiary & $12(10)$ \\
& Yes & $16(\mathrm{n} / \mathrm{a})$ \\
& No & $84(\mathrm{n} / \mathrm{a})$ \\
\hline
\end{tabular}

Tab. 2: Basic characteristics of the survey sample (NOTE: * Share (\%) in the population of Vysocina Region (virtually equivalent to South Moravia Region). Sources: authors' survey and Population Census 2011 
our analyses, we used data from the last three Population Censuses (Czech Statistical Office, 2011) and data on registered unemployment in the years 2000-2011 provided by the Ministry of Labour and Social Affairs (MPSV, 2012).

\section{Results}

\subsection{General perception of the nuclear power plant}

For purposes of comparison (Fig. 2), we used a single question concerning general perceptions of the Dukovany NPP ("What are your feelings when you see the cooling towers of the nuclear power plant?"), with the same terms employed in a previous study of the perceptions of the Temelín NPP (Těšitel et al., 2005, 2008). Dukovany - an older power plant in comparison with Temelín - is perceived and assessed by the majority of our respondents cognitively (as a 'reasonable solution' and a 'technological achievement'), rather than emotionally (as a 'necessary evil', an object of 'discomposure' or 'immediate danger'). Although this literal question was not applied in the earlier surveys in Dukovany (Horská et al., 1996, Vaishar, 1999), it can be inferred that the perception of Dukovany has improved with the length of residents' cohabitation with the power plant, and that the fear of immediate danger was more common during the construction and in the first years of operation.

The levels of 'discomposure' or 'fear of immediate danger' increase with zonal distance from the power plant from the more recent Dukovany study (see Tab. 3). The more positive perception of the power plant by people living closer to it is probably influenced by the effect of habituation, everyday direct contact with the power plant and the familiarisation of risks (risk has become a part of our everyday reality), and also by the more significant economic impacts on communities in close proximity to the power plant. The level of fear of danger is also significantly affected by knowledge and personal experience, i.e. more highly educated people and people who work in the power plant are less likely to feel threatened by such risks.

\subsection{Perception of impacts on people's quality of life}

The results from our survey concerning perceptions of the impacts of the NPP on particular 'spheres' of the quality of life, as defined by indicators of subjective well-being (Massam, 2002, cit. in Těšitel et al., 2008), are presented in Table 4. We used a similar list of items (i.e. individual 'spheres' of the quality of life) as that used in the previous research by Těsitel and colleagues $(2005,2008)$, for a possible comparison of our results with those from the Temelín NPP. From Table 4, it can be seen that only a negligible minority of respondents perceive negative impacts of the Dukovany NPP on their personal well-being. Most residents perceive positive impacts (particularly with respect to the development and image of the communities in which they live, access to public services, and their working activities), or no effects on their personal lives (particularly as regards their life values, relationships, and mental and physical health). These results are clearly more positive compared to the case of the Temelín NPP, where the average assessment

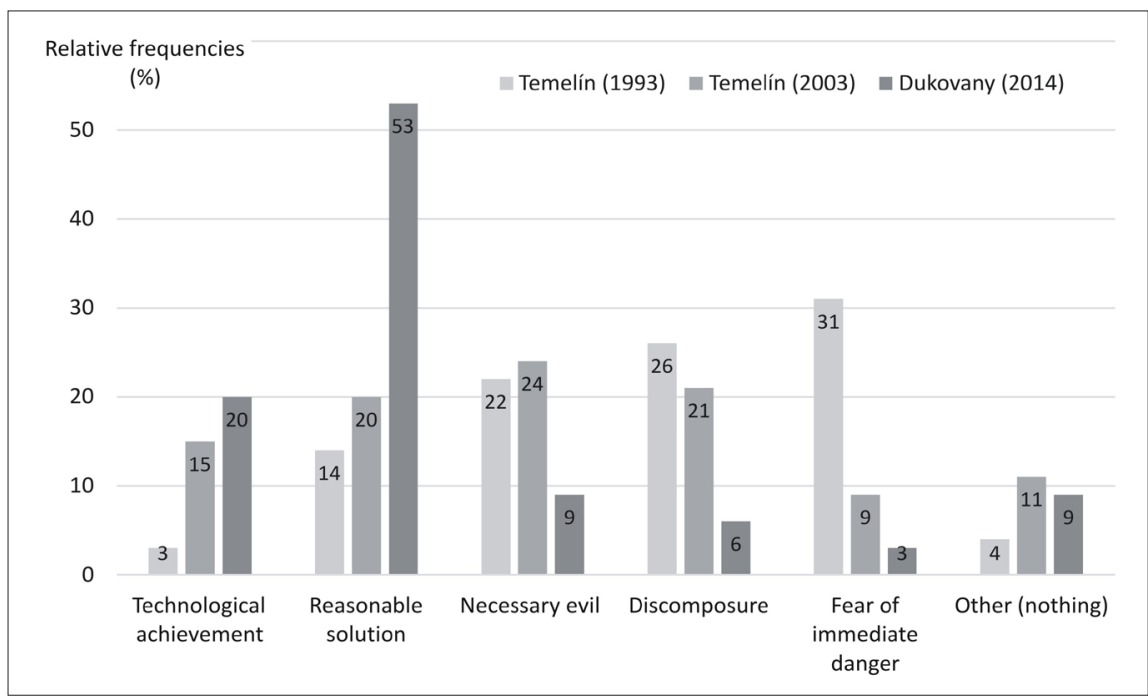

Fig. 2: Perceptions of nuclear power plants in Temelin (1993 and 2003) and Dukovany (2014) Sources: Těšitel et al. (2005) and authors' survey

\begin{tabular}{|c|c|c|}
\hline Indicator & Category & $\begin{array}{l}\text { Share of respondents (\%) who } \\
\text { feel the 'fear of danger' or } \\
\text { 'discomposure' }\end{array}$ \\
\hline \multirow[t]{3}{*}{ Zone } & Zone I & 6.1 \\
\hline & Zone II & 6.6 \\
\hline & Zone III & 20.7 \\
\hline \multirow[t]{2}{*}{ Work in power plant } & Yes & 0.0 \\
\hline & No & 10.2 \\
\hline \multirow[t]{3}{*}{ Education } & Basic & 12.0 \\
\hline & Secondary & 8.0 \\
\hline & Tertiary & 3.2 \\
\hline
\end{tabular}

Tab. 3: Spatial and social differentiation of risk perceptions. Source: authors' survey 


\begin{tabular}{|c|c|c|c|c|c|}
\hline \multirow{2}{*}{ Aspect of personal life } & \multicolumn{3}{|c|}{ Perceived impact [\%] } & \multirow{2}{*}{ Mean } & \multirow{2}{*}{ Variance } \\
\hline & Positive & Neither & Negative & & \\
\hline Community in which I live & 56 & 41 & 3 & 0.54 & 0.30 \\
\hline Access to services & 39 & 60 & 1 & 0.38 & 0.26 \\
\hline Working activities & 31 & 66 & 3 & 0.29 & 0.26 \\
\hline Leisure activities & 15 & 84 & 1 & 0.14 & 0.14 \\
\hline Life values & 10 & 88 & 2 & 0.07 & 0.12 \\
\hline Relationships & 10 & 84 & 6 & 0.05 & 0.16 \\
\hline Mental health & 6 & 90 & 4 & 0.02 & 0.10 \\
\hline Physical health & 6 & 90 & 5 & 0.01 & 0.10 \\
\hline
\end{tabular}

Tab. 4: Perceived impact of the Dukovany nuclear power plant on 'spheres' of the quality of life.

Note: The impact was assessed on a three-point scale: positive impact $(+1)$, no impact (0), and negative impact (-1). Individual aspects are ordered according to descending mean values. Source: authors' survey

of most spheres (except the access to services and everyday activities) were in a 'negative territory' (ranging from -0.1 to -0.4 in case of mental health).

We can assume that, as in the case of the general perceptions of the power plant (see Fig. 2), even in the case of their impact on the quality of life, the perceptions of Dukovany residents are more positive than perceptions of Temelín - presumably because of a longer co-existence of people with the power plant, inducing subsided fears, as well as the positive economic impacts on local development. We found significant differences between zones and municipalities within zones, which are related to the perception of impacts on the communities in which respondents live $(\mathrm{F}=40.86 ; \mathrm{p}<0.001)$, access to services $(\mathrm{F}=14.56 ; \mathrm{p}<0.001)$, and working activities $(\mathrm{F}=18.84$; $\mathrm{p}<0.001$ ). The highest percentage of people who perceive positive impacts in these matters is in the municipalities of Dukovany and Rouchovany (see Tab. 5). The spatial demarcation of emergency zones is also reflected in the proportion of people who work for the power plant - the largest share of workers was reported in the Dukovany municipality (every fourth respondent from this municipality worked in the NPP).

\subsection{The effect of spatial and social distance on perceived impacts}

For purposes of a more detailed analysis, we calculated the overall "index of impact" of the power plant, as a sum of the evaluation scores for all eight aspects of the quality of life. The sum of the eight items resulted in a satisfactory measure of reliability (Cronbach's alpha $=0.68$ ); hence, they were summed to create the overall index. The value of this index can hypothetically range from -8 to +8 . For two thirds $(67 \%)$ of respondents the value of this index is positive, for $27 \%$ the value is zero, and for only $7 \%$ is the

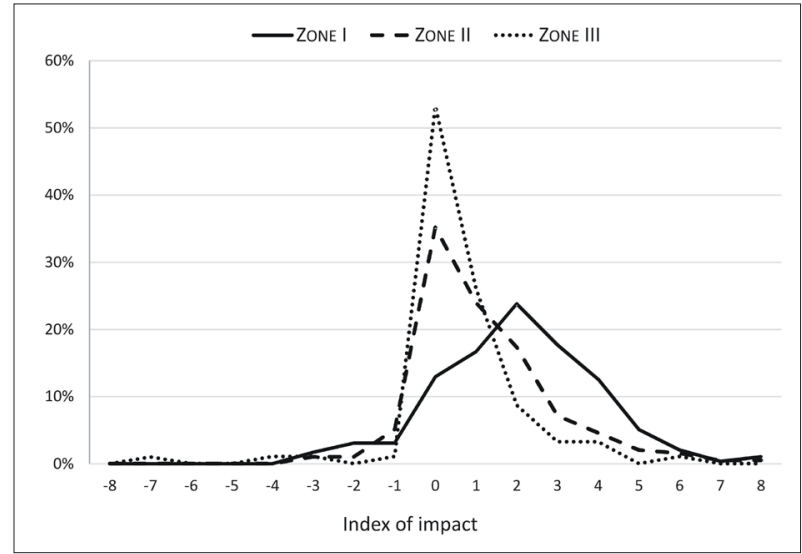

Fig. 3. Distribution of values of the 'index of impact' by emergency zones. Source: authors' survey

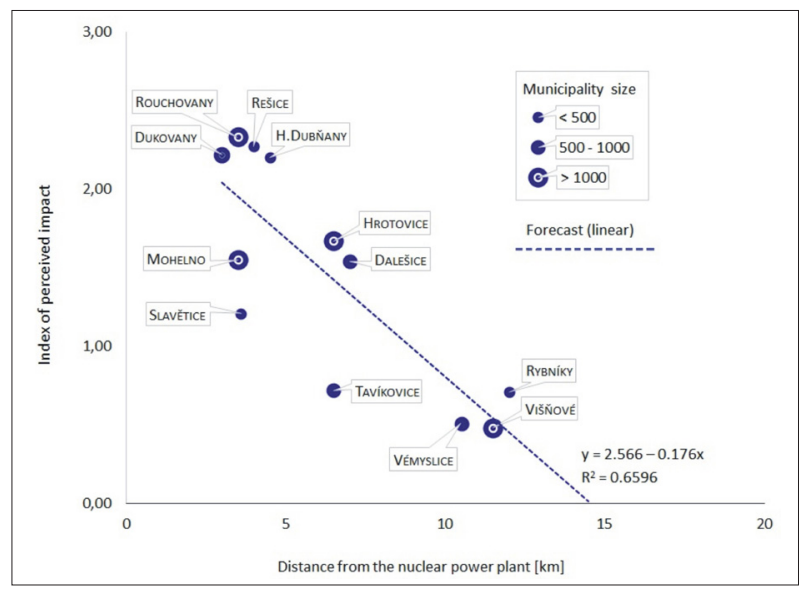

Fig. 4: The relationship between distance of municipality from the power plant and perceived impact Source: authors' survey

\begin{tabular}{|c|c|c|c|c|c|}
\hline \multirow{2}{*}{ Spheres of the quality of life } & \multicolumn{5}{|c|}{ Share $(\%)$ of perception of positive impact } \\
\hline & Zone I & Zone II & Zone III & Dukovany & Rouchovany \\
\hline Community in which I live & 75 & 41 & 29 & 88 & 80 \\
\hline Access to services & 50 & 31 & 24 & 60 & 48 \\
\hline Working activities & 41 & 27 & 11 & 40 & 44 \\
\hline Share $(\%)$ of people working in NPP & 20 & 15 & 3 & 27 & 16 \\
\hline
\end{tabular}

Tab. 5: Spatial differences in perceived positive impacts

Note: Spheres with the largest variance in perceived impact are included. Source: authors' survey 
value negative. The distribution of values of the index according to emergency zones is presented in Figure 3. We found that the mean value of the impact varies significantly depending on the emergency zone. While the average index value for municipalities in the first zone is over 2 , it is only 1.15 in the second zone and 0.57 in the third zone. The mean value of the index for the whole sample is 1.45 .

In addition to the variation by zone, the mean values of the index for specific municipalities (i.e. mean values of resident responses) strongly correlate with the specified geographical distance from the power plant (see Fig. 4).

Based on this linear regression analysis, a hypothetical boundary where the index of impact approaches zero is at a distance of about $15 \mathrm{~km}$ from the power plant. We note that such a spatially-determined distance from the power plant is not the only, and perhaps not even the main determinant, influencing perceptions of its impact. In this sample, nonetheless, the factor of spatial distance explains $66 \%$ of variations in the index of impact. We have also tested whether there is a relationship between the index of impact for municipalities and their size (population), the rate of unemployment, and the sum of donations gained over the period 2008-2011 from the ČEZ company (using data provided by Šilhán, 2011). No correlation was found for the first two variables, but a significant correlation $(r=0.30$; $\mathrm{p}<0.001$ ) was found in the case of donations. These results are obviously affected by the small sample of municipalities, and they must then be interpreted with caution.

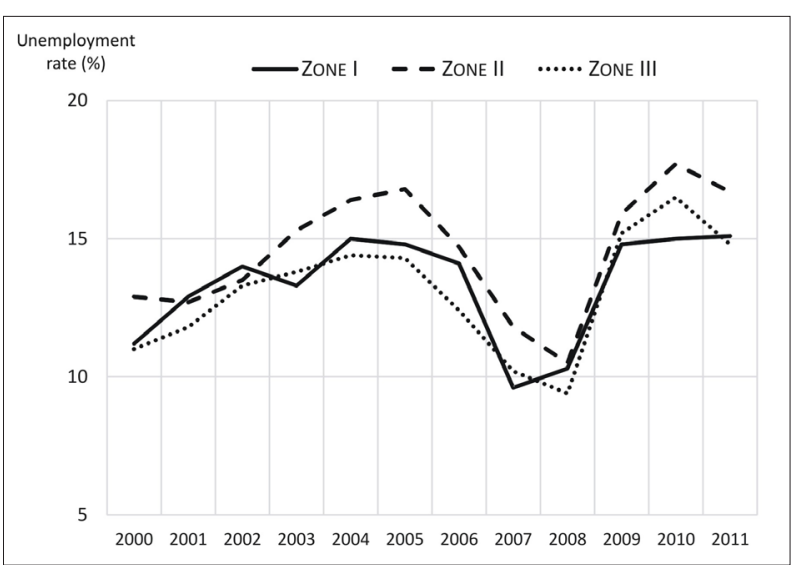

Fig. 5: Development of the unemployment rate within the three emergency zones Source: MPSV (2012), authors' calculations
Devine-Wright (2005) has emphasized that the 'social distance' and the 'location of interest' are usually more important factors affecting public perceptions and attitudes to energy facilities than mere physical proximity. Indeed, we found that in addition to the spatial differences in the perception of positive impacts, there were significant differences according to age, education and occupation (see Tab. 6). Highly educated, young (up to 30 years) and middleaged (30-49 years) economically active people, were more likely to report perceived positive impacts on their personal well-being. Working for the power plant also proved to be a very significant factor affecting perception of positive impacts. The value of the impact index reported by males (1.62) is higher than the value reported by females (1.36), but this difference is not statistically significant.

\subsection{Regional economic impacts of the nuclear power plant}

Large parts of the broader region encompassing the Dukovany NPP (particularly the districts located in the western part of the study area, such as Znojmo and Třebíc) have been among those regions most affected by unemployment in the Czech Republic since the 1990s. Moreover, the wider region has to cope with many other economic and social problems which are characteristic of peripheral areas in the Czech Republic.

With respect to the role of the Dukovany NPP as an important regional employer, we can identify three relatively compact areas with differing rates and long-term development of unemployment. The first area covers the eastern part of the region, i.e. the regional capital of Brno and its hinterland, which is characterized by very low rates of unemployment. Although most of the area surrounding the Dukovany NPP is located in the so-called 'inner periphery' (Musil and Müller, 2008), it has a significantly lower average unemployment rate. In addition, the average unemployment rate of the wider commuting region of the NPP is slightly lower than the national average. We can argue that this area represents a specific region in the settlement system of the Czech Republic, given the effects of the NPP. In a regional context, the Dukovany NPP can be considered as an important centre comparable to secondary centres of the region (such as the cities of Znojmo, Třebíč, Velké Meziř́ičí or Jemnice). Further, the municipalities located beyond the regional reach of Brno city and the Dukovany NPP show some of the highest unemployment rates, not only within this region but also in the Czech Republic as a whole (cf. Ouředníček and Nemeškal, 2015).

\begin{tabular}{llccc}
\hline Independent variables & Yes & $\begin{array}{c}\text { Index of impact } \\
\text { (Mean) }\end{array}$ & F & Sig. \\
\hline Work in/for power plant & No & 3.07 & 87.096 & 0.0001 \\
Education & Basic & 1.20 & 0.0001 \\
& Secondary without GCE & 1.51 & 7.800 & \\
& Secondary with GCE & 1.20 & & 0.0300 \\
Age (years) & Tertiary & 1.47 & & \\
& less than 30 & 2.50 & 2.349 & \\
& $30-49$ & 1.52 & & \\
& $50-59$ & 1.85 & 1.14 & \\
\end{tabular}

Tab. 6: Social differentiation of perceptions of positive impacts (* Index of impact is a sum of evaluation scores for all eight aspects (values can range from -8 to +8 ); ** Result of the ANOVA, F-values and probability levels)

Source: authors' survey 
Jobs in the power plant, the activities connected to its operation, the level of salaries and the employment structure both in the power plant itself and in companies in its supply chain operating in the region, have had a significant effect on the economic level of the wider region. An important role is played by the presence of people with higher economic and social capital and higher purchasing power. The construction of the NPP (in 1974-1987) significantly contributed to the increase of job opportunities in the study area (see Tab. 7). According to Svoboda and Hána (2015), the robust increase in job opportunities in the energy development sector was connected with a significant population increase in municipalities which became new homes for immigrant workers. This is particularly evident in the city of Třebíč, where new housing estates were constructed specifically to house the NPP employees.

Evaluation of the development of unemployment in the period 2000-2011 shows that when there is a nationwide trend of increasing unemployment, the growth of the unemployment rate in the inner periphery is higher than in other parts of the region. Comparison of the development of unemployment rates according to emergency planning zones (see Fig. 5) showed that long-term unemployment is highest within the municipalities of the second zone, which forms a kind of inner periphery within the NPP commuting region. The positive impact of the NPP on employment is also evident from the number of commuters to the Dukovany municipality (see Tab. 1). The number of commuters to Dukovany decreases significantly with distance from the power plant. The average rate of unemployment in municipalities of the third zone proved to be even lower than in the first zone, due to the effect of the suburban growth of Brno and several larger cities that impinge on the third emergency zone. The observed differences in the average unemployment rate for emergency zones, however, proved to be statistically insignificant (except for the years 2005 and 2006).

\section{Discussion and conclusions}

The results of this study indicate that the Dukovany nuclear power plant has had important positive impacts on its surrounding communities and the broader region, both as perceived by local residents and as evidenced by statistical data. These impacts are, however, significantly spatially and socially differentiated. In other words, the level of positive impacts is influenced by both the geographical distance from the power plant and the 'social distance', which is linked to the occupation and socioeconomic status of individuals. In addition, we can also infer a positive effect of 'time distance' (or the years of co-existence with the power plant) on perceptions. Somewhat 'circumstantial' evidence for this argument is seen in that the Dukovany NPP has been perceived both generally (as an object in the landscape) and specifically (in terms of impacts on partial aspects of the quality of life), more positively than the second and more recent Czech NPP in Temelín (cf. Těšitel et al., 2005, 2008).

Generally, local residents are more likely to perceive and report positive impacts of the Dukovany NPP at the community level than at the personal level. The power plant has positively affected the image and development of its neighbouring communities, the regional labour market and public access to services, while minor or negligible impact was perceived with respect to residents' physical and mental health, their life values and relationships. Perceptions of positive impacts are correlated significantly with proximity to the power plant, and positive effects are also more likely to be reported by highly educated, young and middle-aged, economically active respondents whose work is connected to the power plant. In this sense, we can also infer the effects of the "social distance" of people from the power plant.

Our research results are in accordance with an earlier study on perceptions of the Dukovany power plant carried out in the early 1990s (Horská et al., 1996). People living in municipalities situated in the vicinity of the power plant tend to have positive attitudes as they see the economic benefits for their communities, while people from remote communities are more preoccupied with potential security risks and negative consequences, such as visual disruption of the landscape or the decline of property prices. Warren et al. (2005: 866) defined this reverse proximity effect as an "inverse NIMBY syndrome", whereby those with power plants in their backyard area tend to be more supportive of the technology. This kind of acceptance of energy facilities for economic benefits is sometimes also called "Yes In My Backyard" (YIMBY).

The positive impacts on partial aspects of the quality of life are significantly more likely to be perceived by residents living in municipalities of the first emergency zone (up to $5 \mathrm{~km}$ from the power plant). In more remote municipalities, the positive effects of the NPP are less pronounced, and respondents tended to report neither positive nor negative impacts. The hypothetical distance where positive effects on the quality of life are no longer perceived was estimated by linear regression at about $15 \mathrm{~km}$. Our results, however, could be strongly affected by the small sample of municipalities located in the second and the third emergency zones, and they must accordingly be interpreted with caution.

\begin{tabular}{|c|c|c|c|c|c|}
\hline \multirow{2}{*}{ Zone } & \multicolumn{3}{|c|}{$\begin{array}{c}\text { Number of jobs } \\
\text { per economically active population }\end{array}$} & \multicolumn{2}{|c|}{$\begin{array}{l}\text { Employment in the energy sector } \\
\qquad(2011)\end{array}$} \\
\hline & 1991 & 2001 & 2011 & Number & Share $(\%)$ \\
\hline Zone I & 0.60 & 1.92 & 1.24 & 128 & 7.12 \\
\hline Zone II & 0.51 & 0.55 & 0.67 & 134 & 4.23 \\
\hline Zone III & 0.53 & 0.49 & 0.56 & 574 & 0.02 \\
\hline Wider commuting region & 0.58 & 0.50 & 0.56 & 368 & 2.46 \\
\hline Czech Republic & 0.97 & 0.91 & 0.90 & 32,390 & 1.02 \\
\hline
\end{tabular}

Tab. 7: Number of jobs per economically active population and employment in the energy sector according to emergency planning zones. Note: The wider commuting region includes the three zones of emergency planning plus 32 other municipalities belonging to the region on the basis of intensive commuting to work

Source: Population Censuses 1991, 2001, 2011 (CZSO, 2011). 
Similar to our current results, Horská et al. (1996) found that inhabitants of municipalities mentioning positive impacts of the power plant considered the effects on the regional labour market, on the development of the civic and technical infrastructure of municipalities and the overall quality-of-life standard, as the most important aspects. While distance is still significant, our results (compared to Horská et al.) differ as concerns the overall perception of risks: almost $60 \%$ of respondents felt threatened by the power plant ten years after its commissioning at that time (mid-1990s), but nearly twenty years later such feelings have rapidly decreased. The positive effects of time, knowledge and proximity, on public attitudes towards nuclear power plants have also been reported from other countries, such as the UK, USA or France (Eiser et al., 1995; Greenberg, 2009b; Venables et al., 2009)

The concept of "familiarisation of risks" (Parkhill et al., 2010) can be used to support the survey results. The effect of familiarisation is expressed by feelings of risks and unrest that decrease with declining distance from the power plant. As Parkhill et al. (2010) pointed out, such familiarity was engendered through 'growing up' with the power plant (it was something that had always been there and had been part of peoples' everyday lives), and through perception of the power plant as a symbol of home. In addition, familiarity was also reinforced through social networks (the experience of working at the power plant; a worker as a family member or friend). In our study this is reflected in the fact that if a respondent works in the power plant, the perception of it is almost solely positive (this relationship could be termed a strong link of 'social proximity'). This is also closely connected to a higher degree of technical education and knowledge about issues concerning nuclear energy development or any other practices in related industries.

Nevertheless, Venables et al. (2009) stressed that local communities' dependency on the nuclear industry in providing jobs, economic benefits and sponsorship activities, is not the only reason why some people express positive attitudes towards nuclear power plants. According to Bisconti Research (2013), a majority of people associate nuclear energy primarily with reliable electricity, efficiency, clean air, energy security, job creation and affordable electricity. The contribution of nuclear power to increasing national energy security and its role as a kind of 'clean energy' in mitigating global climate change, was included among the top-rated proarguments of nuclear power plants (in general) by a majority of respondents, and this is also seen in the case of this study of Dukovany. The fact that nuclear power plants create job opportunities and retain employment in host regions, is considered their key contribution.

Furthermore, the dominant economic role of NPPs, which may substantively bring significant benefits to local communities, such as jobs, property tax revenues, sponsorship for local activities or a range of other economic multipliers, have, however, often led to something Wynne et al. (2007) call a 'dependency syndrome' for much of the surrounding population. This is probably also the case of the Dukovany NPP, as evidenced by the intense endeavours of local communities in the region to support the renovation of the power plant or even completion of other blocks of the facility. In this context, the extent to which any specific NPP has generated economic benefits for its host region throughout its operational stage and how far these benefits will be reversed on its closure, has to be seriously considered by experts and policy-makers (Lewis, 1986; Tomaney et al., 1999).
The region in which the Dukovany power plant is located can be designated as an area with a predominantly rural peripheral character, which has to cope with many socioeconomic problems, such as a high unemployment rate and few job opportunities (Feřtrová, 2011). Despite these problems, the municipality of Dukovany still maintains the status of an important centre of commuting for work, which distinctly exceeds the importance of municipalities of a similar population size. The Dukovany nuclear power plant is an important employer, which mitigates potential problems of the region by providing job opportunities for a significant proportion of the local population (both directly in the power plant and in its supply chain, across a wider region). In the case of the closure of the power plant and the related reduction of job opportunities, it would be reasonable to expect a significant rise in unemployment and a considerable deepening of the socioeconomic problems of this region.

\section{Acknowledgements}

The research presented in this paper was carried out within the sustainability of the project "Energy landscapes: innovation, development and internationalization of research (No. ESF OP CZ.1.07/2.3.00/20.0025), the longterm institutional support from the Institute of Geonics (RVO: 68145535), and the project TD020354 "Scenarios of future development of the Dukovany nuclear power station's microregion using a Territorial Impact Assessment approach", supported by the OMEGA Programme of the Technology Agency of the Czech Republic. The authors express their sincere gratitude to these supporting agencies.

\section{References:}

BAROCH, P. (2010): Obec Temelín nevzkvétá. I když ČEZ vydělává miliardy [online]. [cit. 10.10.2015] Available at: http://zpravy.aktualne.cz/domaci/obec-temelin-nevzkvetai-kdyz-cez-vydelava-miliardy/r i:article:663436/

BAZILE, F. (2012): Social impacts and public perception of nuclear power. In Alonso, A. [ed.]: Infrastructure and Methodologies for the Justification of Nuclear Power Programmes. A Volume in Woodhead Publishing Series in Energy, 549-566.

BEZDEK, R. H., WENDLING, R. M. (2006): The impacts of nuclear facilities on property values and other factors in the surrounding communities. International Journal of Nuclear Governance, Economy and Ecology, 1(1): 122-144.

BISCONTI RESEARCH (2013): Favorability Toward Nuclear Energy Stronger Among Plant Neighbors Than General Public [online]. [cit. 10.10.2015] Available at: http://www. nei.org/CorporateSite/media/filefolder/Backgrounders/ Reports-Studies/ MEMO-Plant-Neighbors-070113.pdf

BOHOLM, A., LÖFSTED, R. [eds.]: (2004): Facility sitting: Risk, Power and Identity in Land Use Planning. London: Earthscan.

BRODY, C. J. (1984): Differences by sex in support for nuclear power. Social Forces, 63(1): 209-228.

CLARK, D. E., MICHELBRINK, L., ALLISON, T., METZ, W. C. (1997): Nuclear power plants and residential housing prices. Growth and Change, 28(4): 496-519.

COOPER, M. (2010): Policy challenges of nuclear reactor construction: Cost escalation and crowding out alternatives [online]. [cit. 10.10.2015] Available at: http://www.ises.org. il/assets/files/News/20100909_cooperStudy.pdf 
CVVM (Public Opinion Research Centre) (2015): Veřejnost o energetice - květen 2015 [online]. [cit. 10.10.2015] Available at: http://cvvm.soc.cas.cz/media/com form2content/ documents/c1/a7392/f3/oe150609.pdf

CZSO (Czech Statistical Office) (2013): Cenzus 2011 [online]. [cit. 10.10.2015] Available at: https://www.czso.cz/csu/sldb

DAKE, K. (1992): Myths of nature: culture and social construction of risk. Journal of Social Issues, 48(4): 21-37.

DAVIS, L.W. (2011): The effect of power plants on local housing values and rents. Review of Economics and Statistics, 93(4): 1391-1402.

DEAR, M. (1992): Understanding and overcoming the NIMBY syndrome. Journal of the American Planning Association, 58: 288-300.

DEVINE-WRIGHT, P. (2005): Beyond NIMBYism: Towards an Integrated Framework for understanding Public Perceptions of Wind Energy. Wind Energy, 8(2): 125-139.

EISER, J. R., SPEARS, R., WEBLEY, P. (1989): Nuclear Attitudes Before and After Chernobyl: Change and Judgment. Journal of Applied Social Psychology, 19(8): 689-700.

EISER, J. R., VAN DER PLIGT, J., SPEARS, R. (1995): Nuclear Neighbourhoods. Exeter: Exeter University Press.

ENERGOREGION 2020 (2016): Sdružení obcí region JE Dukovany [online]. [cit. 10.02.2016] Available at: http:// portal.energoregion.cz/o-nas-a-kontakt/

ETHINGTON, P. J. (1997). The intellectual construction of "Social Distance": Toward a recovery of Georg Simmel's social geometry. Cybergeo: European Journal of Geography, 30 [online]. [cit. 10.02.2016] Available at: http://www.cybergeo.presse.fr/essoct/texte/socdis.htm

EUROSTAT (2015): Renewable energy statistics [online]. [cit. 10.10.2015] Available at: http://ec.europa.eu/eurostat/ statistics-explained/index.php/Renewable_energy_statistics

FEŘTROVÁ, M. (2011): Nezaměstnanost a sociální dávky. In: Ouředníček, M., Temelová, J., Pospíšilová, L. [eds.]: Atlas sociálně prostorové diferenciace České republiky (pp. 37-38). Praha: Nakladatelství Karolinum.

FISCHHOFF, B., SLOVIC, P., LICHTENSTEIN, S., READ, S., COMBS, B. (1978): How safe is safe enough? A psychometric study of attitudes towards technological risks and benefits. Policy Sciences, 9: 127-152.

FISCHHOFF, B., SLOVIC, P., LICHTENSTEIN, S. (1983): "The Public" Vs. "The Experts": Perceived Vs. Actual Disagreements About Risks of Nuclear Power. In: Covello, V.T. et al. [eds.]: The analysis of actual versus perceived risks (pp. 235-249). New York, Springer US.

FLYNN, J., SLOVIC, P., MERTZ, C. K. (1994): Gender, Race, and perception of environmental health risks. Risk Analysis, 14(6): 1101-1108.

FRANTÁL, B. (2015): Have local government and public expectations of wind energy project benefits been met? Implications for repowering schemes. Journal of Environmental Policy \& Planning, 17(2): 217-236.

GAMBLE, H. B., DOWNING, R. H. (1982): Effects of nuclear power plants on residential property values. Journal of Regional Science, 22(4): 457-478.

GLASSON, J. (2005): Better monitoring for better impact management: the local socio-economic impacts of constructing Sizewell B nuclear power station. Impact Assessment and Project Appraisal, 23(3): 215-226.
GOODFELLOW, M. J., WILLIAMS, H. R., AZAPAGIC, A. (2011): Nuclear renaissance, public perception and design criteria: An exploratory review. Energy Policy, 39(10): 6199-6210.

GREENBERG, M. (2009a): How much do people who live near major nuclear facilities worry about those facilities? Analysis of national and site-specific data. Environmental Planning and Management, 52(7): 919-937.

GREENBERG, M. (2009B): NIMBY, CLAMP, and the Location of New Nuclear-Related Facilities: U.S. National and 11 Site-Specific Surveys. Risk Analysis, 29(9): 1242-1254.

GREENBERG, M., TRUELOVE, H. B. (2011): Energy choices and risk beliefs: is it just global warming and fear of a nuclear power plant accident?. Risk Analysis, 31(5): 819-831.

HORSKÁ, H., MIKULÍK, O., VAISHAR, A., ZAPLETALOVÁ, J. (1996): Perception of the Dukovany nuclear power plant (Czech Republic) by local population. Moravian Geographical Reports, 4(2): 19-34.

ISARD, W., REINER, T., VAN ZELE, R., STRATHAM, J. (1976): Regional economic impacts of nuclear power plants. Philadelphia: Pennsylvania University, Department of Regional Science.

JAHN, D., KOROLCZUK, S. (2012): German exceptionalism: the end of nuclear energy in Germany. Environmental Politics, 21(1): 159-164.

JOHNSON, M. H., BENNETT, J. T. (1979). An input-output model of regional environmental and economic impacts of nuclear power plants. Land Economics, 236-252.

JONES, C. R., EISER, J. R. (2010): Understanding 'local' opposition to wind development in the UK: How big is a backyard? Energy Policy, 38(6): 106-3117.

LEWIS, P. M. (1986): The economic impact of the operation and closure of a nuclear power station. Regional Studies, 20(5): 425-432.

LINDELL, M. K., PERRY, R. W. (1990): Effects of the Chernobyl accident on public perceptions of nuclear plant accident risks. Risk Analysis, 10(3): 393-399.

MASSAM, B. H. (2002): Quality of Life: Public Planning and Private Living. Progress in Planning 58: 141-227.

MADERTHANER, R., GUTTMANN, G., SWATON, E., OTWAY, H. J. (1978): Effect of distance upon risk perception. Journal of Applied Psychology, 63(3): 380-382.

MCGUIRE, A. (1983): The regional income and employment impacts of nuclear power stations. Scottish Journal of Political Economy, 30(3): 264-274.

METZ, W. C. (1994): Potential negative impacts of nuclear activities on local economies: rethinking the issue. Risk Analysis, 14(5): 763-770.

MPSV (Ministry of Labour and Social Affairs) (2012): Časové řady: Průměrná míra nezaměstnanosti od roku 1997 [online]. [cit. 10.10.2015] Available at: http://portal. mpsv.cz/sz/stat/nz/casove_rady

MUSIL, J., MÜLLER, J. (2008): Vnitřní periferie v České republicejako mechanismus sociální exkluze. Sociologický časopis/Czech Sociological Review, 44(2): 321-348.

OUŘEDNÍČEK, M., NEMEŠKAL, J. (2015): Vývoj nezaměstnanosti $\mathrm{v}$ obcích $\mathrm{v}$ širokém okolí Jaderné elektrárny Dukovany 1991-2011. Specializovaná mapa. In: Špačková, P. [ed.]: Vývoj stavu sociálních a ekonomických podmínek $\mathrm{v}$ širokém okolí Jaderné 
elektrárny Dukovany [online]. [cit. 10.10.2015] Available at: http://www.atlasobyvatelstva.cz/cs/dukovany

PAMPEL, F. C. (2011): Support for nuclear energy in the context of climate change: Evidence from the European Union. Organization \& Environment, 24(3): 249-268.

PARKHILL, K. A., PIDGEON, N. F., HENWOOD, K. L., SIMMONS, P., VENABLES, D. (2010): From the familiar to the extraordinary: local residents' perceptions of risk when living with nuclear power in the UK. Transactions of the Institute of British Geographers, 35(1): 39-58.

PEELLE, E. (1976): Socioeconomic effects of operating reactors on two host communities: a case study of Pilgrim and Millstone. Tennessee: Oak Ridge National Laboratory.

PIDGEON, N., HENWOOD, K., SIMMONS, P. (2009): Living near nuclear power plants. People \& Science, 3: 14-15.

PRATI, G., ZANI, B. (2013): The effect of the Fukushima nuclear accident on risk perception, antinuclear behavioral intentions, attitude, trust, environmental beliefs, and values. Environment and Behavior, 45(6): 782-798.

SIEGRIST, M., VISSCHERS, V.H. (2013): Acceptance of nuclear power: the Fukushima effect. Energy Policy, 59: $112-119$.

SIEGRIST, M., SÜTTERLIN, B., KELLER, C. (2014): Why have some people changed their attitudes toward nuclear power after the accident in Fukushima? Energy Policy, 69: 356-363.

ŠILHÁN, Z. (2011): Jaderná elektrárna Dukovany a její vliv na okolní obce. Diploma Thesis. Brno: Masaryk University.

SLOVIC, P., LICHTENSTEIN, S., BISCHHOFF, B. (1979): Images of disaster: perception and acceptance of risks from nuclear power. Electric Perspectives, 3: 8-20.

SLOVIC, P. (1987): Perception of risk. Science, 236(4799): $280-285$.

STARR, C. (1969): Social benefit versus technological risk. Readings in Risk, 183-194.

SVOBODA, P., HÁNA, D., NEMEŠKAL, J. (2015): Pracovní př́ležitosti v obcích v širokém okolí Jaderné elektrárny Dukovany 1991-2011. Specializovaná mapa. In: Špačková, P. [ed.]: Vývoj stavu sociálních a ekonomických podmínek v širokém okolí Jaderné elektrárny Dukovany [online]. [cit. 10.10.2015] Available at: http://www. atlasobyvatelstva.cz/cs/dukovany.

SWOFFORD, J., SLATTERY, M. (2010): Public attitudes of wind energy in Texas: Local communities in close proximity to wind farms and their effect on decisionmaking. Energy Policy, 38(5): 2508-2519.

TĚŠITEL, J., KUŠOVÁ, D., BARTOŠ, M. (2005): Temelín power plant as an unusual landscape feature. Ekológia, 24(Suppl. 1): 139-149.

TĚŠITEL, J., KUŠOVÁ, D., BARTOŠ, M. (2008): Temelín v kontextu obytné krajiny. Životné prostredie, 42(2): 85-88.

TOMANEY, J., PIKE, A., CORNFORD, J. (1999): Plant closure and the local economy: the case of Swan Hunter on Tyneside. Regional Studies, 33(5): 401-411.
VAISAR, A. (1999): Vývoj názorové hladiny obyvatelstva a prognóza sociálního rozvoje v oblasti vlivu energetické soustavy Dukovany - Dalešice. In: Hanus, V. [ed.]: O vlivu provozu jaderných elektráren na životní prostředí (pp. 19-30). Praha, Česka nuklearní společnost a Česka vědeckotechnická společnost.

VAN DER HORST, D. (2007): NIMBY or not? Exploring the relevance of location and the politics of voiced opinions in renewable energy sitting controversies. Energy Policy, 35(5): 2705-2714.

VAN DER PLIGT, J. (1985): Public attitudes to nuclear energy: salience and anxiety. Journal of Environmental Psychology, 5(1): 87-97.

VAN DER PLIGT, J., EISER, J. R., SPEARS, R. (1986): Attitudes toward Nuclear Energy Familiarity and Salience. Environment and Behavior, 18(1): 75-93.

VENABLES, D., PIDGEON, N. F, SIMMONS, P., HENWOOD, K. L., PARKHILL, K.A. (2009): Living with Nuclear Power: A Q-Method Study of Local Community Perceptions. Risk Analysis, 29(8): 1089-1104.

VENABLES, D., PIDGEON， N. F., PARKHILL， K. A., HENWOOD, K. L., SIMMONS, P. (2012): Living with nuclear power: Sense of place, proximity, and risk perceptions in local host communities. Journal of Environmental Psychology, 32(4): 371-383.

VISSCHERS, V. H., KELLER, C., SIEGRIST, M. (2011): Climate change benefits and energy supply benefits as determinants of acceptance of nuclear power stations: investigating an explanatory model. Energy Policy, 39(6): 3621-3629.

VISSCHERS, V. H., SIEGRIST, M. (2012): Fair play in energy policy decisions: Procedural fairness, outcome fairness and acceptance of the decision to rebuild nuclear power plants. Energy Policy, 46: 292-300.

WALKER, C., BAXTER, J., OUELLETTE, D. (2014): Beyond rhetoric to understanding determinants of wind turbine support and conflict in two Ontario, Canada communities. Environment and Planning A, 46(3): 730-745.

WARREN, C. R., LUMSDEN, C., O'DOWD, S., BIRNIE, R. V. (2005): Green on green: public perceptions of wind power in Scotland and Ireland. Journal of Environmental Planning and Management, 48(6): 853-875.

WNA (World Nuclear Association) (2015): Nuclear Power in the World Today [online]. [cit. 10.10.2015] Available at: http://www.world-nuclear.org/info/Current-and-FutureGeneration/Nuclear-Power-in-the-World-Today/

WYNNE, B., WATERTON, C., GROVE-WHITE, R. (1992/2007): Public Perceptions and the Nuclear Industry in West Cumbria. Lancaster: Lancaster University, Centre for the Study of Environmental Change.

YAMANE, F., OHGAKI, H., ASANO, K. (2011): Social Factors Affecting Economic Welfare of the Residents around Nuclear Power Plants in Japan. Energy Procedia, 9: 619-629. 